\title{
Goedschalige samenwerking in de regio
}

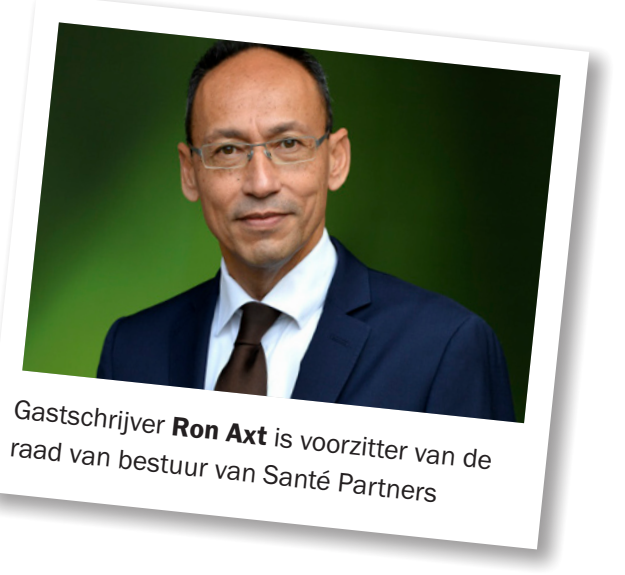

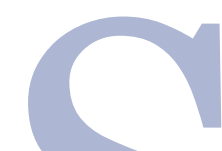

Santé Partners is sinds 1 januari de naam van de gefuseerde organisaties STMR en Vitras. Het werkgebied van de organisatie is uitgestrekt en reikt van Gorinchem tot Duitsland en van Utrecht tot's-Hertogenbosch. Daarbinnen zijn kleinschaligheid en lokale verbondenheid uitstekend te organiseren. Een voordeel van het uitgestrekte werkgebied is dat je leert van de ervaringen van de diverse regio's. Meer ontwikkelkracht realiseren was de belangrijkste reden van de fusies. Zodat we (nieuwe) diensten beter op de klantvraag kunnen laten aansluiten, de medewerkers voldoende kunnen equiperen met kennis en competenties en technologie nog slimmer inzetten. Gezamenlijk kunnen we dat beter, maar vooral door regionaal intensiever samen te werken. Aan de voorkant moeten klanten en stakeholders profijt van de fusie hebben. Aan de achterkant moet je de organisatie op passende schaal organiseren zodat je voldoende ontwikkelpotentie hebt en kostenefficiënt kunt werken. Op ontwikkel- en executiekracht zou geen enkele organisatie moeten bezuinigen.

Duurzame oplossingen voor vraagstukken in de zorg vinden we niet in ons huidige stelsel of door het macrobudget te verhogen. We moeten vooral kritisch kijken naar welke zorg, waar en vanuit welke deskundigheid wordt geleverd. Thuis, in de wijk, waar het kan en via de huisarts en het ziekenhuis waar het moet. Schotten in organisaties, professionele verantwoordelijkheid en de financiering moeten we meer loslaten. In de regio Rivierenland organiseren we vier keer per jaar een rondetafelbijeenkomst met zorgverzeke- raars, ziekenhuis, huisartsengroepen en VVT-organisaties. We bespreken een of twee regionale vraagstukken en werken gezamenlijk aan een oplossing. Ook het zorgkantoor, gemeenten en welzijnsorganisaties schuiven aan.

\section{Technologie en krapte}

Technologie is belangrijk. Het helpt niet alleen onze professionals, maar ook in de klantbeleving. Denk aan digitale waardemetingen en consulten die klanten thuis kunnen doen. De spanning voor een grootschalige inzet van technologie zit ook in de privacy wetgeving en de diversiteit aan datasystemen waarmee we in de sector werken. Werk bij dit soort innovaties daarom samen met organisaties die maatschappelijk willen investeren en zorg voor enige schaalomvang.

De krapte op de arbeidsmarkt is het gesprek van de dag. Het gaat ons echter niet lukken om binnen vijf jaar 120.000 vacatures in te vullen. Natuurlijk moeten we er hard aan blijven werken om medewerkers te boeien en te binden. Maar de oplossing op de korte termijn zie ik vooral in de logistieke samenwerking tussen cure en care en de inzet van professionals over de organisaties heen in de totale keten. Ook dit moet op regionaal niveau vorm krijgen. Ook het verlagen van de administratieve lastendruk en het terugdringen van de bureaucratie zijn goede stappen. Begin bij uw eigen organisatie. U zult versteld staan van wat u zelf bedacht heeft. Deze beweging kan zeker vijf tot tien procent meer capaciteit vrijmaken. 